\title{
Stable Isotope Analysis Reveals the Importance of Riparian Resources as Carbon Subsidies for Fish Species in the Daning River, a Tributary of the Three Gorges Reservoir, China
}

\author{
Huatang Deng ${ }^{1,2}$, Yun Li ${ }^{1, *(\mathbb{D})}$, Mingdian Liu ${ }^{2}$, Xinbin Duan ${ }^{2}$, Shaoping Liu ${ }^{2}$ \\ and Daqing Chen ${ }^{2, *}$ \\ 1 College of Animal Science and Technology, Southwest University, Chongqing 400715, China; \\ denght@yfi.ac.cn \\ 2 Yangtze River Fisheries Research Institute, Chinese Academy of Fishery Science, Wuhan 430223, China; \\ liumd@yfi.ac.cn (M.L.); duan@yfi.ac.cn (X.D.); lsp@yfi.ac.cn (S.L.) \\ * Correspondence: aquatics@swu.edu.cn (Y.L.); chdq@yfi.ac.cn (D.C.); Tel.: +86-23-6825-1962 (Y.L.); \\ $+86-027-8178-0058$ (D.C.)
}

Received: 7 August 2018; Accepted: 11 September 2018; Published: 12 September 2018

\begin{abstract}
The patterns of carbon flow in large rivers influenced by dams are still not well known. We hypothesized that spatial variation in fish assimilation of basal production sources would be affected by heterogeneity of landscape-scale hydrology within a watershed due to the impoundment. We used stable isotope analysis and Bayesian mixing models to estimate relative contributions of basal production sources to fish consumers in a tributary of the Three Gorges Reservoir (TGR) with remarkably heterogeneous habitats between the upper and lower reaches. Model estimates indicated that riparian $C_{3}$ plants were the main basal food source irrespective of reaches or feeding groups. Autochthonous algae carbon also appeared to be important as secondary carbon sources. However, the major contributive aquatic algae in the upstream were benthic algae while planktonic algae were important in the downstream, and this difference was related to their distinct hydrological characteristics. The contribution from $\mathrm{C}_{4}$ plants was comparatively less important to all fish consumers. Our results highlighted the significance of the riparian $\mathrm{C}_{3}$ carbon source to fish consumers in the TGR tributary and that the difference in landscape-scale characteristics was not enough to influence the pattern, which may be attributed to abundant standing stock of the riparian plants as well as hydrologic regimes in this river.
\end{abstract}

Keywords: river impoundment; basal carbon source; stable isotope; Three Gorges Reservoir

\section{Introduction}

Deciphering the dominant carbon sources and energy pathways in riverine food webs is fundamental for understanding ecosystem function, with implications for future fluvial management and conservation. The sources and transport of carbon and energy in large river ecosystems have been conceptualized as several theoretical concepts, including the river continuum concept (RCC) [1], the flood pulse concept (FPC) [2] and the riverine productivity model (RPM) [3]. Each conceptual model has stressed the importance of organic matter originating from autochthonous or allochthonous sources [4]; such as the RCC stressing subsidy from upstream processing of terrestrial organic matter [1], the FPC emphasizing lateral river floodplain exchanges [2], and the RPM highlighting carbon derived from local in-stream production [5-7]. Owing to the hydrogeomorphic diversity among or within large river systems however, a single conceptual model of carbon dynamics is unlikely to apply to 
all rivers or to one river with various habitat units included $[8,9]$. Therefore, a more comprehensive concept, such as the Riverine Ecosystem Synthesis (RES), which regards rivers as arrangements of large hydrogeomorphic patches (functional process zones), is proposed to synthesize various river ecosystem concepts $[10,11]$. This new holistic and generalized concept has been developing recently in, for example, the river wave concept [12]. Moreover, anthropogenic influences, such as dam construction, land uses, and hydrological modification, can change subsidy pathways [13-17] and thereby intensify unpredictability of the variation. As a result, the most important carbon source supporting riverine food webs would vary depending on the temporal and spatial patterns of all kinds of environmental conditions $[4,18,19]$.

Dams alter hydrologic conditions in the river, which affect the life cycles of river biota and species interactions in the food webs, and thereby change some ecosystem processes [20]. The creation of lentic habitats in the reservoir can causes the dominant carbon source to change along with increasing the importance of algal production $[8,16]$, especially downstream from the reservoir where exporting pelagic-derived production from the reservoir could subsidize the food web [13,21,22]. Although tributaries contributing to the overall biodiversity of large rivers [23] are also likely to be changed in hydrogeomorphic nature due to the impoundment, carbon flow in these influenced tributaries is less focused.

The Yangtze River is by far the largest river in China. The Three Gorges Dam (TGD) was constructed near Yichang city in Hubei province, where the Yangtze River's middle and upper reaches meet. The dam is $185 \mathrm{~m}$ high and impounds the Three Gorges Reservoir (TGR), which is $600 \mathrm{~km}$ in length with a total storage capacity of approximately $39.3 \times 10 \mathrm{~km}^{9} \mathrm{~m}^{3}$. The TGR began filling on 1 June 2003. Hydrologic regulation is carried out according to flood control, which gradually draws down to its lowest water level at $145 \mathrm{~m}$ prior to the flood season near April, and maintains a normal pool level at $175 \mathrm{~m}$ after the flood season, usually from October. There are ten tributaries with a watershed area larger than $1000 \mathrm{~km}^{2}$ joining the Yangtze River within the Three Gorges Reservoir Area. After impoundment of the TGR, the lower reaches of these tributaries are submerged by backwater and deep lacustrine habitats are formed with the same fluctuation cycle as the mainstream. The upper streams, however, maintain natural fluvial conditions. In the early stage of TGR operation, terrestrial $\mathrm{C}_{3}$ plants and $\mathrm{C}_{4}$ plants were testified as being the dominant carbon source to consumers which collected from the mainstream sites in the reservoir [24]. Another study conducted in the backwater area of Xiaojiang River, which is also a TGR tributary but more affected by anthropogenic activities, demonstrated that microalgae and terrestrial $\mathrm{C}_{4}$ plants were the main energy sources for economically important fish before and after the impoundment, respectively [25]. The Daning River is a typical tributary in the TGR with heterogeneous habitats, and the river continuity and natural landscape are undamaged and effectively protected. The carbon pathway in this tributary after TGR impoundment is still unclear.

The objective of this study was to ascertain the main carbon contributions to the aquatic food web in a tributary of the TGR with heterogeneous habitats. We hypothesized that there were different carbon pathways between the upper and lower river reflecting the heterogeneity of landscape-scale hydrology within the watershed, and that fish species from the upper river relied mainly on terrestrial carbon while the lower river depended on the autochthonous carbon. We further explored the contribution difference of carbon source among fish species with distinct feeding strategies in order to identify the influence of the feeding strategy on the contributions. To test the hypothesis, we analyzed and compared carbon and nitrogen stable isotope ratios of the principal primary production sources and fish consumers in the river. Bayesian mixing models were used to determine the relative importance of different food sources. 


\section{Materials and Methods}

\subsection{Study Area and Site Descriptions}

The Daning River is a tributary of the Yangtze River, located in the middle of the Three Gorges Reservoir (Figure 1). The River flows in a southerly direction for approximately $200 \mathrm{~km}$ from its headwaters to the reservoir at Wushan City, $123 \mathrm{~km}$ upstream of the Three Gorges Dam, draining a catchment of $4426 \mathrm{~km}^{2}$. Due to the hydrologic regulation of the TGR, the downstream of the river forms a backwater area $60 \mathrm{~km}$ in length with a mean depth of approximately $40 \mathrm{~m}$ when the water level rises to $175 \mathrm{~m}$ (October-February), and $47 \mathrm{~km}$ long and $23 \mathrm{~m}$ deep at the lowest water level of $145 \mathrm{~m}$ [26]. The water velocity in this area is less than $0.04 \mathrm{~m} / \mathrm{s}$ after the impoundment. The river is canyon-shaped with three long gorges in the lower reaches, characterized by an incised channel with steep littoral zones. Meanwhile, there are several large open sections scattered in backwater areas with less steep slopes and wide lateral habitats characterized by muddy substrates sprouting dense macrophyte mats during lower water levels. The fluctuation of water level results in a long perpendicular fluctuating belt in the incised channels, and a vast periodic inundated area up to a total of $15 \mathrm{~km}^{2}$ in the open zone [27]. The upper reaches of the river remain a typical fluvial habitat with a 10-30 m wide alluvial flat. The upstream is 5-10 $\mathrm{m}$ wide and 1-3 $\mathrm{m}$ deep at low-flow periods, with a gravel-cobble substrate and a pool-riffle morphology. This reach has a gradient of approximately $8 \mathrm{~m} / \mathrm{km}$ and a water velocity of more than $1.5 \mathrm{~m} / \mathrm{s}$. The main land uses in the watershed include $22.2 \%$ cropland, $11.4 \%$ grassland, and $65.8 \%$ forest [28]. However, most of the farming land is distributed in the downstream area where the elevation is below $800 \mathrm{~m}$.

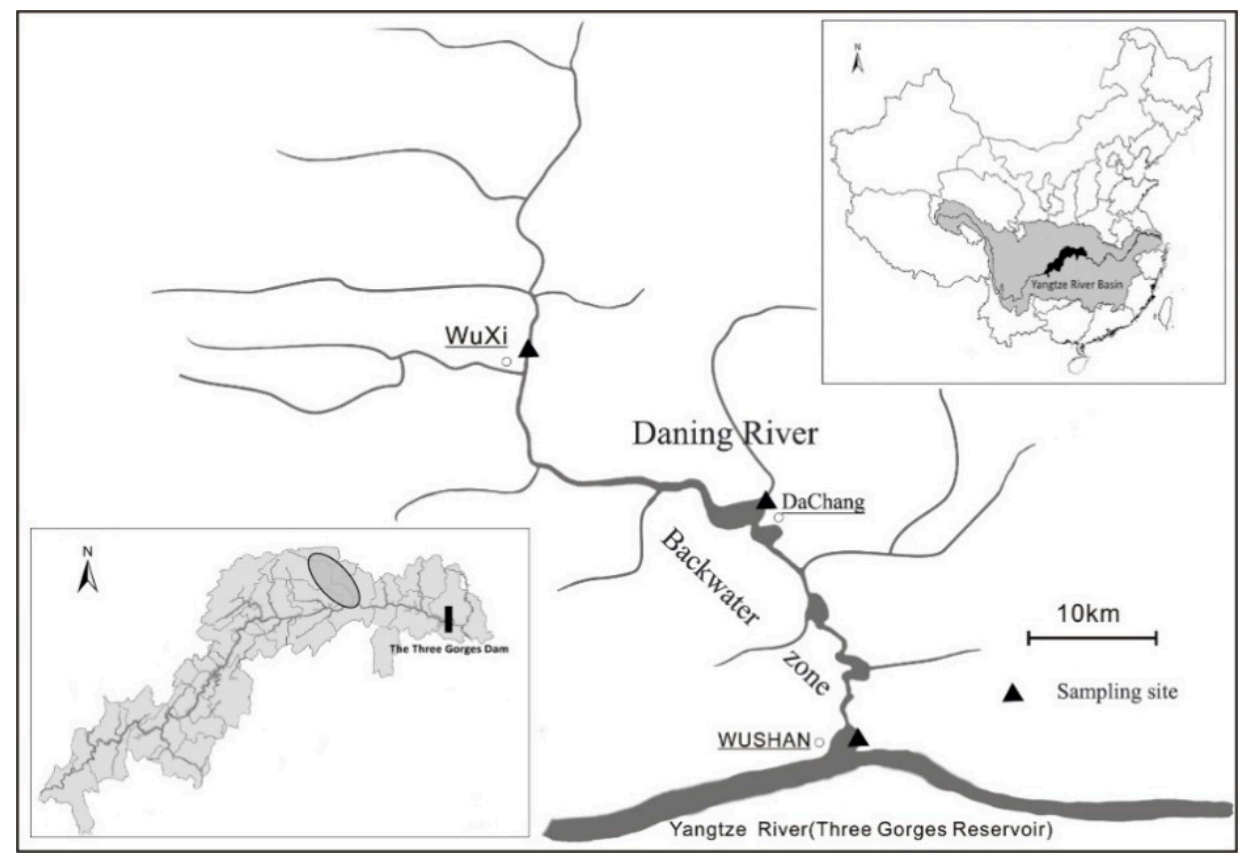

Figure 1. The location of the Three Gorges Reservoir Region and the sampling sites in the Daning River.

\subsection{Sample Collection and Analysis}

Samples were collected from two different types of habitats. Two sites (Wushang, Dachang) in the backwater zone downstream represent lacustrine habitats and one upstream site (Wuxi) represents riverine systems in the Daning River (Figure 1). Sampling was carried out during flood season (May-June), dry season (December), drawdown (March) and impoundment (September-October) periods from 2012 to 2013.

Potentially important basal carbon sources of aquatic and terrestrial origin were aggregated as four major groups according to previous studies in TGR and other rivers $[9,24]$ : Riparian $C_{3}$ plants, 
terrestrial $C_{4}$ plants, benthic algae and seston. The dominant terrestrial vegetation was collected from the riparian zone, including: Polygonum hydropiper, Conyza canadensis, Alternanthera philoxeroides, and Xanthium sibiricum for $\mathrm{C}_{3}$ plants; and Cynodon dactylon, Cyperus rotundus, Eleusine indica, Setaria faberii, crops (corn seedlings) and tree leaves for $\mathrm{C}_{4}$ plants. Plant samples were air dried, placed in plastic bags and transported to the laboratory for further processing. Benthic algae (attached algae, mostly filamentous) were scraped directly off accessible stable substrate surface. Samples were rinsed with distilled water repeatedly, and any sediment particles, detritus or microorganisms were removed during examination under a microscope. Seston was filtered from a composite water sample containing samples from several depths (surface, $5 \mathrm{~m}, 15 \mathrm{~m}$ at downstream sites, and surface at upstream) with a water bottle at each site. Water samples were pre-filtered through a $112 \mu \mathrm{m}$ plankton net to remove zooplankton and large detritus. Seston samples were then obtained by filtering water through a pre-combusted $\left(450^{\circ} \mathrm{C}, 4 \mathrm{~h}\right)$ Whatman GF/C $(1.2 \mu \mathrm{m})$ filter using a manual pump. Microscopic examination showed that the seston were composed mostly of phytoplankton and suspended particulate organic matter of undetermined origin.

Fish were captured using $2 \mathrm{~m}$ by $50 \mathrm{~m}$ gillnets with a wide range of mesh sizes $(30,60,80$ and $120 \mathrm{~mm}$ ). The number and weight of fish species collected were recorded. A total of 38 fish species (28 for downstream, 15 for upstream) were selected for isotopic analysis based on the abundance and frequency of capture in several surveys [29]. For each species, only large adult individuals were selected in case of the influence of ontogenetic diet shifts on isotopic value. According to the literature, five feeding groups are found in the 28 selected downstream species [30-33], including planktivores, herbivores, benthivores, omnivores and piscivores. Because of no evident feeding differentiation for the upstream fish species, most of which are omnivores [30,32], the comparison of fish with feeding groups came from downstream. For selected individuals, fish were weighed $(\mathrm{g})$, measured $(\mathrm{mm})$, and dissected to extract approximately $5-10 \mathrm{~g}$ of dorsal muscle tissue for isotopic analysis.

All samples were dried to a constant weight for at least $48 \mathrm{~h}$ at $60^{\circ} \mathrm{C}$ and crushed to a homogeneous fine powder using a mortar and pestle. Samples were then sent to the Stable Isotope Laboratory, Chinese Academy of Forestry, Beijing, China, for analysis of carbon and nitrogen isotope ratios using a Flash EA1112 HT Elemental Analyzer coupled to a DELTA V Advantage Isotope Ratio Mass Spectrometer. Stable isotope ratios are expressed as delta $(\delta)$ and defined as parts per thousand $(\%)$ relative to the laboratory standard material: $\delta \mathrm{X}=\left(R_{\text {sam }}-R_{\text {std }}\right) / R_{\text {std }} \times 10^{3} \%$, where $\mathrm{X}$ is ${ }^{13} \mathrm{C}$ or ${ }^{15} \mathrm{~N}$ and $\mathrm{R}$ is the corresponding ratio ${ }^{13} \mathrm{C} /{ }^{12} \mathrm{C}$ or ${ }^{15} \mathrm{~N} /{ }^{14} \mathrm{~N}$. The standard material for carbon is Pee Dee Belemnite (PDB) limestone, and the nitrogen standard is atmospheric nitrogen. Precision of the isotopic analysis was $0.1 \%$ for carbon and $0.2 \%$ for nitrogen.

\subsection{Bayesian Mixing Model}

Bayesian isotopic mixing models in the Stable Isotope Analysis in R (SIAR) package [34] were employed to estimate relative contributions of basal production sources to each fish consumer for each habitat. These models account for uncertainties associated with sample variability and trophic enrichment on the assumption they are normally distributed [34]. The average and standard deviations of $\delta^{13} \mathrm{C}$ and $\delta^{15} \mathrm{~N}$ of each food source and fish collected from lotic or lentic reaches were used separately as input values for the SIAR models for that habitat. Although $C_{3}$ and $C_{4}$ riparian plants are widespread along the river channel, most of them are not evenly distributed. In order to include all the possible allochthonous sources fish could assimilate to, mean source values (with variation) combined across all sites were used for $\mathrm{C}_{3}$ and $\mathrm{C}_{4}$ plants in either downstream or upstream analyses. Trophic enrichment values were $0.4 \pm 0.19 \%$ for $\delta^{13} \mathrm{C}[35]$ and $3.4 \pm 0.13 \%$ of $\delta^{15} \mathrm{~N}$ [36] in all models. Through a Markov chain Monte Carlo method, each mixing model was fit to generate simulations of plausible values for dietary proportions consistent with the data using a Dirichlet prior distribution [34]. Each model was run for 200,000 iterations, using non-informative priors to guide the dietary proportion simulations. Upper and lower 95\% credibility intervals were used to describe the range of feasible contributions for each food source to each fish consumer [34]. The solution with the highest probability produced by the 
model, instead of the mean value of all the possible solutions, was utilized to evaluate and compare the discrepancy among reaches or feeding groups.

\subsection{Statistical Analyses}

The Shapiro-Wilk's test and Levene's test were used to test the normality and homogeneity of variances for $\delta^{13} \mathrm{C}$ and $\delta^{15} \mathrm{~N}$ isotopic signatures data respectively, before comparing the differences among basal food sources $(n=4)$ and reaches $(n=2)$. The nonparametric Kruskal-Wallis test, followed by Dunn's post-hoc tests were used when the data did not consistently meet the normality assumption. Otherwise, one-way ANOVA with Tukey's post-hoc tests were employed when data were normally distributed. Between-group differences of the combined source contributions were analysed using similarity tests with the Bray-Curtis coefficient as a dissimilarity index (ANOSIM, with 5000 permutations). When there were significant differences, a similarity of percentage analysis (SIMPER) was used to determine dissimilarity for each pair-wise combination of feeding groups and the relative contribution of each carbon source to between-group differences. A $t$-test was used to compare contribution proportions of primary food sources in different reaches. Statistical analyses were conducted using IBM SPSS Statistics (16.0) and PAST3. Statistical significance was determined at $p=0.05$.

\section{Results}

\subsection{Isotopic Signatures}

The $\delta^{13} \mathrm{C}$ values of the basal carbon sources in the Daning River spanned a broad range from $-33.41 \%$ to $-10.44 \%$ (Figures 2 and 3, and Table S1). There were significant differences among the $\delta^{13} \mathrm{C}$ signatures of the four basal production sources for both downstream (ANOVA, $\mathrm{F}=31.44, p<0.01$ ) and upstream (ANOVA, $\mathrm{F}=38.62, p<0.01$ ). Riparian $\mathrm{C}_{3}$ plant signatures were more depleted in $\delta^{13} \mathrm{C}$ than lentic benthic algae and terrestrial $C_{4}$ plants, whereas they had no significant difference with seston in $\delta^{13} \mathrm{C}$ from the downstream. However, $\mathrm{C}_{3}$ plants were the most depleted carbon source in the upstream, while seston was more enriched in $\delta^{13} \mathrm{C}$ than benthic algae at the upper reaches. In addition, seston $\delta^{13} \mathrm{C}$ signatures appeared to be significantly different between the lower and upper reaches (ANOVA, $\mathrm{F}=18.88, p<0.01$ ). Although the $\delta^{15} \mathrm{~N}$ values of the basal carbon sources also varied largely from $-0.39 \%$ to $11.99 \%$ (Figures 2 and 3 and Table S1), differences in $\delta^{15} \mathrm{~N}$ among the four basal production sources were not significant in the downstream (ANOVA, $\mathrm{F}=0.73, p=0.542$ ) or upstream (ANOVA, $\mathrm{F}=2.15, p=0.112$ ). There were no significant differences in $\delta^{15} \mathrm{~N}$ between the lower and upper reaches for each basal carbon source.

The $\delta^{13} \mathrm{C}$ and $\delta^{15} \mathrm{~N}$ signatures of fish varied from $-29.74 \%$ to $-16.61 \%$ and from $2.25 \%$ to $17.51 \%$, respectively (Figures 2 and 3, and Table S1). There were no significant differences in fish consumer $\delta^{13} \mathrm{C}$ between the upstream and downstream (ANOVA, $\mathrm{F}=0.62, p=0.434$ ). However, the fish species collected from the lower reaches had consistently higher $\delta^{15} \mathrm{~N}$ values than those from the upper reaches (ANOVA, $\mathrm{F}=55.10, p<0.01$ ). 


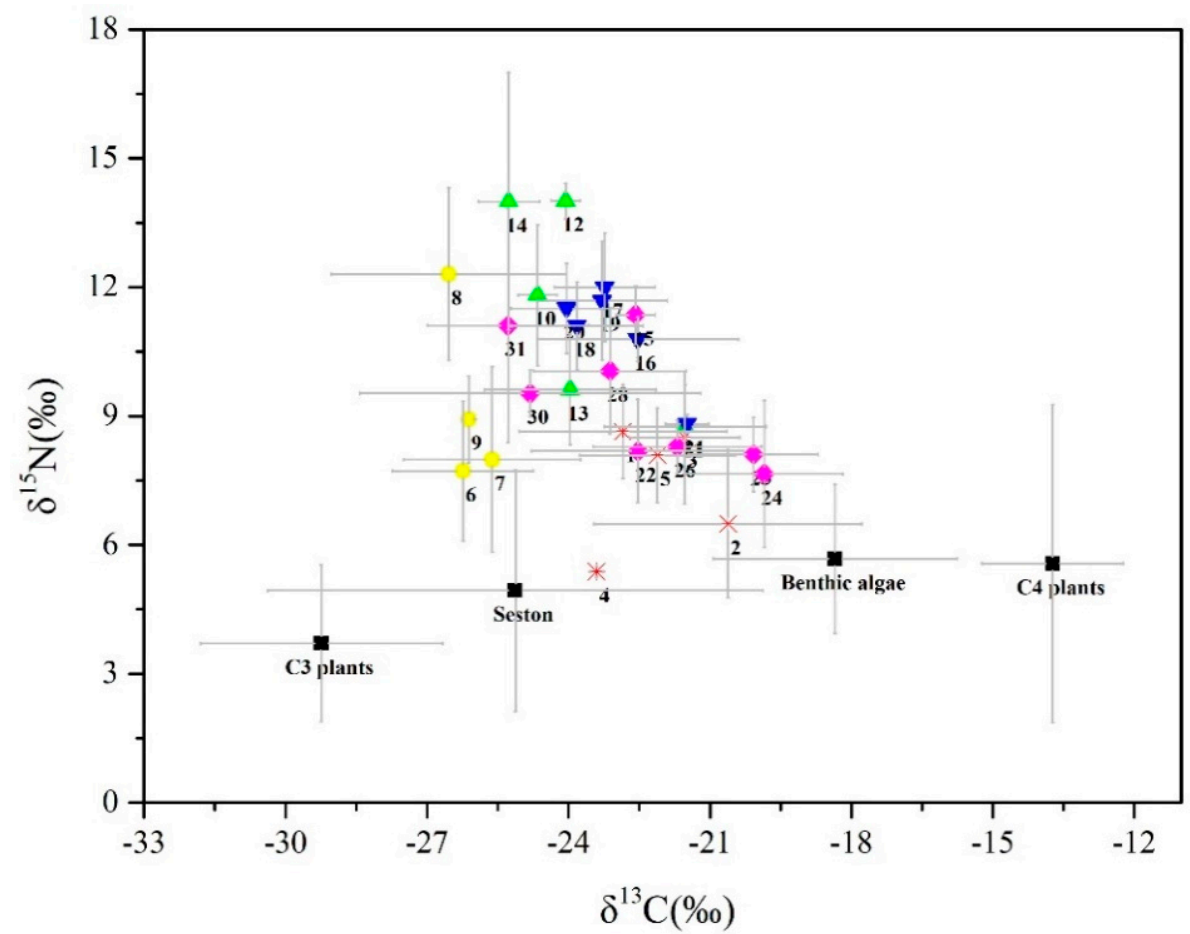

Figure 2. Biplot of $\delta^{13} \mathrm{C}$ and $\delta^{15} \mathrm{~N}$ values (mean value and standard deviation) of basal organic carbon sources and fish collected from the downstream (backwater zone) of the Daning River. The fish species code was in accordance with Table 1. Black square, organic matter sources; green triangle, benthivores; blue inverted triangle, piscivores; violet diamond, omnivores; yellow dot, planktivores; red star, herbivores.

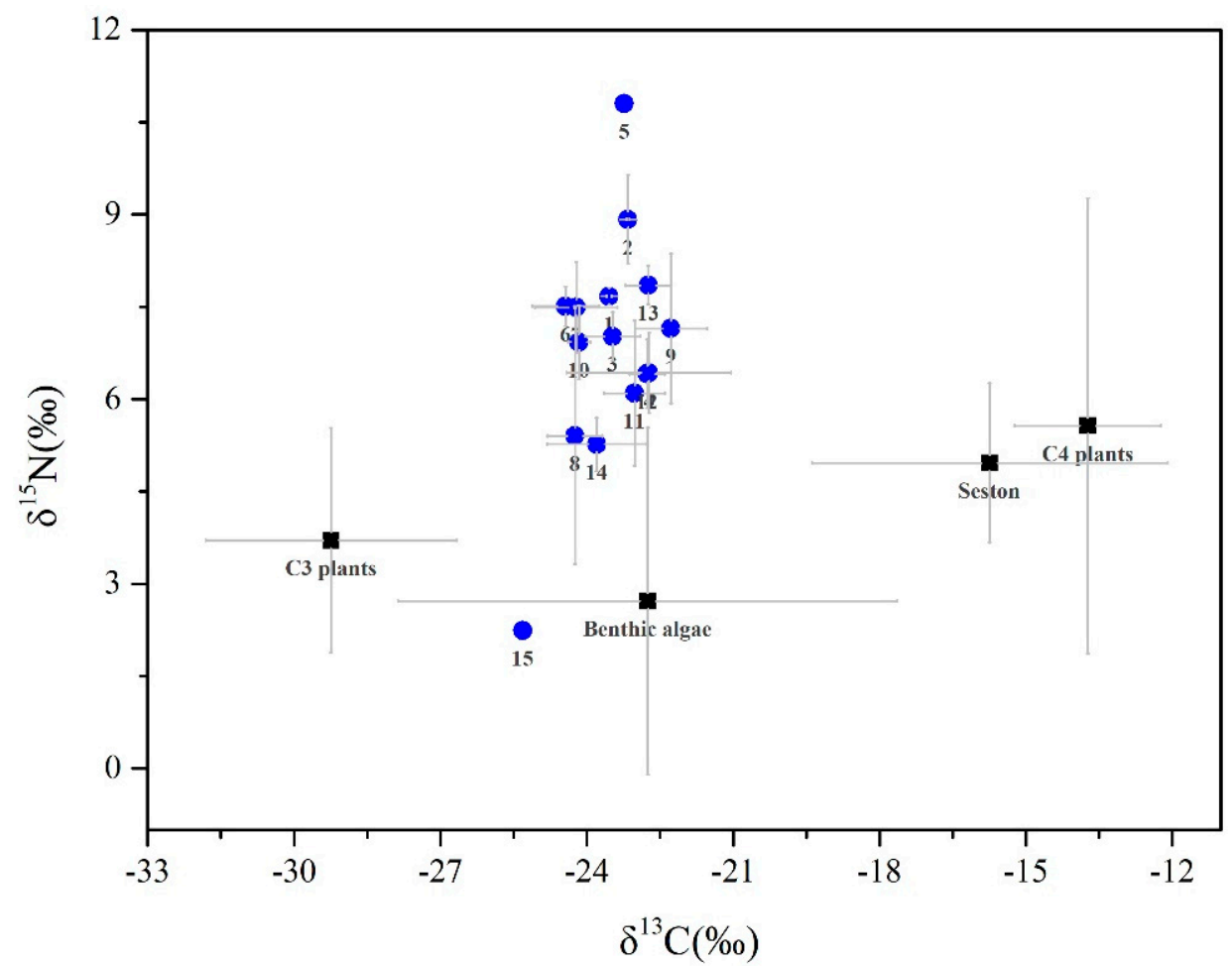

Figure 3. Biplot of $\delta^{13} \mathrm{C}$ and $\delta^{15} \mathrm{~N}$ values (mean value and standard deviation) of basal organic carbon sources (black square) and fish (blue dot) collected from the upstream of the Daning River. The fish species code was in accordance with Table 2. 
Table 1. Bayesian isotopic mixing model estimates of the highest likely percent contributions $(95 \% \mathrm{BCI}$, Bayesian credibility interval) of basal carbon sources to different feeding types of fish species collected from the downstream (backwater zone) of the Daning River.

\begin{tabular}{|c|c|c|c|c|c|}
\hline Code & Taxa & $\mathrm{C}_{3}$ Plants & Benthic Algae & Seston & $\mathrm{C}_{4}$ Plants \\
\hline & Herbivores & & & & \\
\hline 1 & Parabramis pekinensis & $0.31(0.10-0.49)$ & $0.31(0.02-0.50)$ & $0.31(0.02-0.48)$ & $0.13(0.00-0.31)$ \\
\hline 2 & Ctenopharyngodon idella & $0.27(0.03-0.46)$ & $0.27(0.00-0.45)$ & $0.27(0.00-0.46)$ & $0.30(0.06-0.48)$ \\
\hline 3 & Squaliobarbus curriculus & $0.30(0.03-0.46)$ & $0.29(0.00-0.49)$ & $0.27(0.00-0.44)$ & $0.25(0.02-0.43)$ \\
\hline 4 & Megalobrama amblycephala & $0.33(0.03-0.56)$ & $0.26(0.00-0.45)$ & $0.29(0.00-0.48)$ & $0.21(0.00-0.40)$ \\
\hline \multirow[t]{2}{*}{5} & Spinibarbus sinensis & $0.31(0.08-0.50)$ & $0.30(0.01-0.49)$ & $0.28(0.01-0.43)$ & $0.19(0.01-0.37)$ \\
\hline & Planktivores & & & & \\
\hline 6 & Hypophthalmichthys molitrix & $0.71(0.46-0.85)$ & $0.04(0.00-0.21)$ & $0.06(0.00-0.40)$ & $0.02(0.00-0.15)$ \\
\hline 7 & Aristichthys nobilis & $0.55(0.33-0.80)$ & $0.04(0.00-0.26)$ & $0.26(0.00-0.47)$ & $0.03(0.00-0.18)$ \\
\hline 8 & Neosalanx taihuensis & $0.38(0.06-0.75)$ & $0.05(0.00-0.39)$ & $0.33(0.00-0.59)$ & $0.03(0.00-0.31)$ \\
\hline \multirow[t]{2}{*}{9} & Hyporhamphus intermedius & $0.31(0.02-0.62)$ & $0.26(0.00-0.45)$ & $0.28(0.00-0.51)$ & $0.05(0.00-0.40)$ \\
\hline & Benthivores & & & & \\
\hline 10 & Silurus asotus & $0.43(0.20-0.70)$ & $0.19(0.00-0.38)$ & $0.31(0.01-0.49)$ & $0.03(0.00-0.25)$ \\
\hline 11 & Myxocyprinus asiaticus & $0.32(0.11-0.53)$ & $0.27(0.00-0.45)$ & $0.27(0.00-0.43)$ & $0.25(0.02-0.41)$ \\
\hline 12 & Pelteobagrus nitidus & $0.36(0.10-0.64)$ & $0.24(0.00-0.42)$ & $0.31(0.01-0.51)$ & $0.03(0.00-0.31)$ \\
\hline 13 & Pelteobagrus vachelli & $0.52(0.29-0.72)$ & $0.05(0.00-0.34)$ & $0.30(0.00-0.45)$ & $0.07(0.00-0.25)$ \\
\hline \multirow[t]{2}{*}{14} & Coreius heterodon & $0.42(0.13-0.73)$ & $0.08(0.00-0.38)$ & $0.32(0.01-0.52)$ & $0.03(0.00-0.28)$ \\
\hline & Piscivores & & & & \\
\hline 15 & Culter dabryi dabryi & $0.28(0.04-0.45)$ & $0.32(0.02-0.51)$ & $0.32(0.03-0.52)$ & $0.13(0.00-0.32)$ \\
\hline 16 & Siniperca kneri & $0.40(0.22-0.58)$ & $0.28(0.01-0.45)$ & $0.24(0.01-0.40)$ & $0.10(0.00-0.29)$ \\
\hline 17 & Elopichthys bambusa & $0.36(0.15-0.61)$ & $0.29(0.00-0.43)$ & $0.30(0.01-0.48)$ & $0.05(0.00-0.28)$ \\
\hline 18 & Culter mongolicus & $0.34(0.10-0.57)$ & $0.27(0.00-0.45)$ & $0.29(0.01-0.48)$ & $0.12(0.00-0.32)$ \\
\hline 19 & Culter alburnus & $0.43(0.23-0.63)$ & $0.28(0.01-0.42)$ & $0.27(0.01-0.44)$ & $0.04(0.00-0.25)$ \\
\hline \multirow[t]{2}{*}{20} & Leiocassis longirostris & $0.30(0.09-0.50)$ & $0.30(0.01-0.49)$ & $0.23(0.00-0.41)$ & $0.24(0.02-0.40)$ \\
\hline & Omnivores & & & & \\
\hline 21 & Hemiculter leucisculus & $0.35(0.18-0.58)$ & $0.08(0.00-0.41)$ & $0.30(0.00-0.44)$ & $0.22(0.01-0.35)$ \\
\hline 22 & Carassius auratus & $0.28(0.12-0.43)$ & $0.25(0.01-0.44)$ & $0.10(0.00-0.33)$ & $0.33(0.16-0.50)$ \\
\hline 23 & Cyprinus carpio & $0.25(0.06-0.42)$ & $0.26(0.00-0.46)$ & $0.18(0.00-0.38)$ & $0.31(0.14-0.53)$ \\
\hline 24 & Opsariichthys bidens & $0.31(0.04-0.51)$ & $0.28(0.00-0.47)$ & $0.29(0.00-0.46)$ & $0.21(0.00-0.39)$ \\
\hline 25 & Pseudobrama simoni & $0.32(0.14-0.52)$ & $0.25(0.00-0.45)$ & $0.25(0.00-0.41)$ & $0.23(0.02-0.39)$ \\
\hline 26 & Squalidus argentatus & $0.36(0.18-0.55)$ & $0.31(0.01-0.46)$ & $0.30(0.01-0.44)$ & $0.09(0.00-0.29)$ \\
\hline 27 & Hemiculter bleekeri & $0.34(0.08-0.60)$ & $0.30(0.00-0.46)$ & $0.28(0.01-0.49)$ & $0.04(0.00-0.33)$ \\
\hline 28 & Saurogobio dabryi & $0.46(0.25-0.73)$ & $0.11(0.00-0.32)$ & $0.33(0.01-0.52)$ & $0.02(0.00-0.20)$ \\
\hline
\end{tabular}

Table 2. Bayesian isotopic mixing model estimates of the highest likely percent contributions ( $95 \% \mathrm{BCI}$, Bayesian credibility interval) of basal carbon sources to fish species collected from the upstream of the Daning River.

\begin{tabular}{cccccc}
\hline Code & Taxa & $\mathbf{C}_{3}$ Plants & Benthicalgae & Seston & $\mathbf{C}_{4}$ Plants \\
\hline 1 & Trilophysa bleekeri & $0.33(0.01-0.60)$ & $0.29(0.00-0.54)$ & $0.25(0.00-0.43)$ & $0.09(0.00-0.41)$ \\
2 & Rhinogobius cliffordpopei & $0.41(0.13-0.66)$ & $0.33(0.01-0.52)$ & $0.04(0.00-0.37)$ & $0.03(0.00-0.33)$ \\
3 & Hemibarbus labeo & $0.42(0.20-0.68)$ & $0.32(0.00-0.52)$ & $0.06(0.00-0.34)$ & $0.03(0.00-0.29)$ \\
4 & Onychostoma macrolepis & $0.34(0.07-0.61)$ & $0.31(0.00-0.52)$ & $0.16(0.00-0.41)$ & $0.04(0.00-0.37)$ \\
5 & Siniperca kneri & $0.36(0.09-0.63)$ & $0.30(0.00-0.50)$ & $0.25(0.00-0.44)$ & $0.14(0.00-0.34)$ \\
6 & Glyptothorax fukiensis & $0.43(0.11-0.72)$ & $0.34(0.00-0.56)$ & $0.04(0.00-0.36)$ & $0.04(0.00-0.33)$ \\
7 & Paracobitis variegatus & $0.46(0.26-0.73)$ & $0.32(0.01-0.55)$ & $0.04(0.00-0.28)$ & $0.02(0.00-0.24)$ \\
8 & Carassius auratus & $0.32(0.02-0.62)$ & $0.30(0.00-0.52)$ & $0.04(0.00-0.44)$ & $0.06(0.00-0.43)$ \\
9 & Acrossocheilus monticolus & $0.36(0.11-0.60)$ & $0.29(0.00-0.51)$ & $0.12(0.00-0.41)$ & $0.14(0.00-0.36)$ \\
10 & Zacco platypus & $0.56(0.30-0.73)$ & $0.26(0.00-0.51)$ & $0.04(0.00-0.26)$ & $0.02(0.00-0.23)$ \\
11 & Cyprinus carpio & $0.34(0.03-0.58)$ & $0.30(0.00-0.52)$ & $0.21(0.00-0.43)$ & $0.11(0.00-0.41)$ \\
12 & Schizothorax prenanti & $0.34(0.02-0.57)$ & $0.30(0.00-0.52)$ & $0.21(0.00-0.43)$ & $0.18(0.00-0.41)$ \\
13 & Saurogobio dabryi & $0.39(0.18-0.63)$ & $0.33(0.02-0.54)$ & $0.08(0.00-0.36)$ & $0.04(0.00-0.32)$ \\
14 & Discogobio yunnanensis & $0.49(0.26-0.71)$ & $0.33(0.00-0.50)$ & $0.05(0.00-0.31)$ & $0.04(0.00-0.26)$ \\
15 & Spinibarbus sinensis & $0.28(0.00-0.49)$ & $0.27(0.00-0.49)$ & $0.29(0.00-0.48)$ & $0.27(0.00-0.48)$ \\
\hline
\end{tabular}




\subsection{Contributions of Basal Carbon Sources}

The Bayesian isotope mixing model indicated that riparian $C_{3}$ plants were the primary carbon source for fish in both lower and upper reaches (Tables 1 and 2). In the downstream, the lower 95\% credibility intervals of $\mathrm{C}_{3}$ plants for all 28 fish species were consistently greater than 0.02 . The average lower and upper $95 \%$ credibility intervals for $C_{3}$ plants were 0.14 and 0.59 , respectively. Meanwhile, the highest likely contributions of $\mathrm{C}_{3}$ plants estimated from the Bayesian model for each species ranged from 0.25 to 0.71 , with an average proportion of 0.37 . However, the lower $95 \%$ credibility intervals of the other three basal carbon sources for a great number of fish species (seston for 15 species, benthic algae for 20 species, $C_{4}$ plants for 19 species) from the downstream were less than 0.01. The average upper $95 \%$ credibility intervals for seston, benthic algae, and $\mathrm{C}_{4}$ plants were $0.46,0.42$, and 0.34 , respectively. Moreover, the simulated likely contributions to the downstream fish species were $0.06-0.33$ (average $=0.27$ ) for seston and 0.04-0.32 (average $=0.22$ ) for benthic algae. The lowest average contributions of terrestrial $C_{4}$ plants were observed for these fish species from the limnetic zone, as the average proportion was 0.13 .

Similar to the downstream site, the model results revealed that all 15 fish species collected from the upstream derived the majority of their carbon from $\mathrm{C}_{3}$ plants (Table 2), with the average lower $95 \%$ credibility intervals equal to 0.12 and upper $95 \%$ credibility intervals at 0.64 . The simulated most likely contributions of $\mathrm{C}_{3}$ plants from the Bayesian model varied between 0.28 and 0.56 with an average of 0.39 . The contribution from benthic algae to each fish species was relatively low, as only three fish species had lower 95\% credibility intervals greater than zero, although the upper 95\% credibility intervals were typically greater than $50 \%$. On average, benthic algae contributed 0.30 of production (between 0.26 and 0.34 ) to each upstream fish species. As for the contribution from seston and $\mathrm{C}_{4}$ plants, the lower $95 \%$ credibility intervals for all upstream fish were zero while the average upper $95 \%$ credibility intervals were merely 0.38 and 0.35 , respectively. Consequently, these two basal carbon sources had the lower contributions for seston at 0.12 and $C_{4}$ plants at 0.08 on average.

\subsection{Spatial Variability in Contribution}

Significant differences were observed in the contribution proportions of four basal carbon sources between the downstream and upstream (ANOSIM, $\mathrm{R}=0.29, p<0.01$ ). The between-reaches dissimilarity was 23.68 , which was explained as $35.7 \%$ for seston, $22.78 \%$ for $C_{4}$ plants, $20.81 \%$ for $C_{3}$ plants and $20.71 \%$ for benthic algae, respectively. Furthermore, the average contribution proportions of benthic algae for all fish species in the downstream were significantly lower than those in the upstream ( $t$-test, $t=-4.263, p<0.01$; Figure 4A) whereas the average proportions of downstream seston contributions were significantly higher than the upstream ( $t$-test, $t=5.424, p<0.01$; Figure $4 \mathrm{~A})$. There was no difference in the contribution of $\mathrm{C}_{3}$ plants $(t$-test, $t=-0.726, p=0.472)$ or $\mathrm{C}_{4}$ plants $(t$-test, $t=1.891, p=0.066$ ) between the two reaches (Figure $4 \mathrm{~A}$ ).

A comparison between the omnivorous fishes from the downstream and all upstream fishes was also conducted. There were significant differences in contribution proportions of basal sources between the downstream and upstream (ANOSIM, $\mathrm{R}=0.39, p<0.01$ ). Dissimilarity between them was 23.74 and $33.32 \%$ of seston explained this dissimilarity. Only the contribution from $\mathrm{C}_{3}$ plants showed no significant differences between the upper and lower reaches ( $t$-test, $t=-1.782, p=0.089$; Figure 4B). There were significant differences between the upstream and downstream in contribution proportions of benthic algae ( $t$-test, $t=-2.422, p<0.05)$, seston $(t$-test, $t=3.365, p<0.01)$ and $C_{4}$ plants $(t$-test, $t=2.529, p<0.05)$ (Figure 4B). 



Figure 4. Comparison of the highest likely contributions of four basal carbon sources to fish species between the downstream (backwater zone) and the upstream. (A) All fish species from the downstream and upstream; (B) only omnivorous fish from the downstream and all of the upstream fish. Boxes show the interquartile range, and whiskers show the 10th and 90th percentiles. The median and mean values are shown as a horizontal line and cross in the middle of the box, respectively.

\subsection{Differences in Contribution Among Feeding Groups}

The composite contributions of four basal carbon sources were significantly different among feeding groups from the lower reaches (ANOSIM, $\mathrm{R}=0.17, p<0.05$ ) (Figure 5). Intergroup dissimilarities ranged from $10.77 \%$ to $33.03 \%$ with the overall average dissimilarity of $20.18 \%$ (Table 3 ). Planktivores differed significantly from herbivores $(R=0.65, p<0.01)$, omnivores $(R=0.36, p<0.05)$ and piscivores $(\mathrm{R}=0.46, p<0.05)$; and benthivores were significantly distinguishable from herbivores $(\mathrm{R}=0.45, p<0.05)$ and piscivores $(\mathrm{R}=0.28, p<0.05)$, respectively. No significant differences were found for other pair-wise comparisons among feeding groups. $\mathrm{C}_{4}$ plants were observed as having the largest contribution $(30.45 \%)$ to the between-group differences when all feeding groups were included, followed by benthic algae (27.65\%), $C_{3}$ plants $(26.72 \%)$ and seston $(15.18 \%)$. In addition, for each basal carbon source, the relative contributions were significantly different among feeding guilds from the lower reaches, except for seston (Kruskal-Wallis test, benthic algae: $p<0.01$; seston: $p=0.559$; $\mathrm{C}_{3}$ plants: $p=0.059 ; \mathrm{C}_{4}$ plants: $p=0.036$ ) (Figure 5).

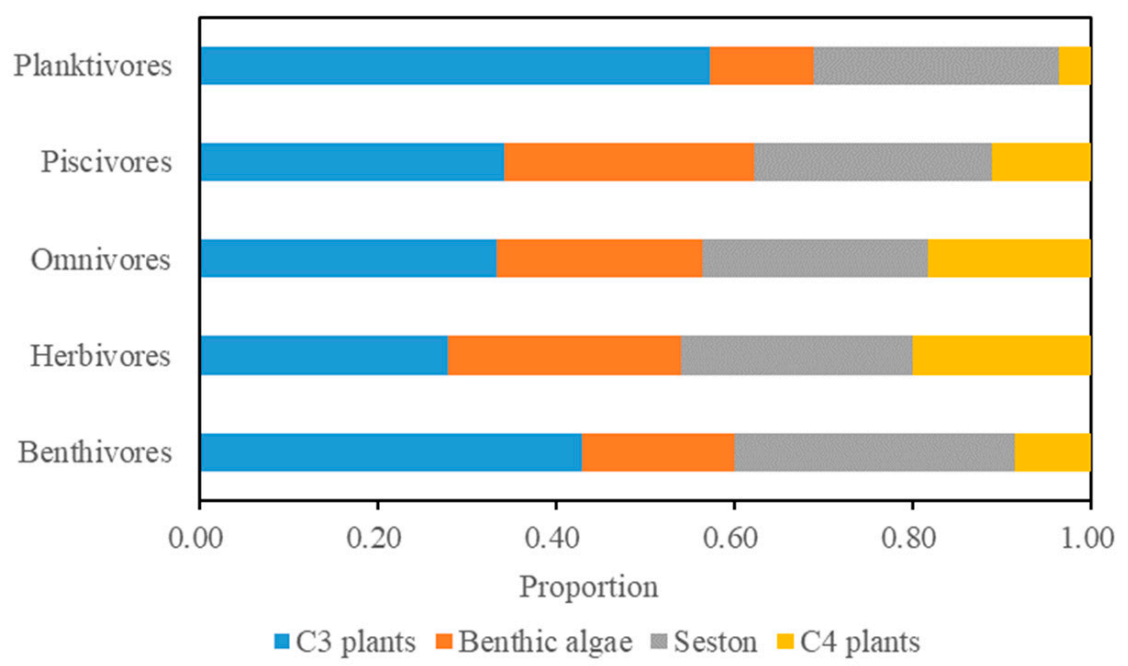

Figure 5. Averages of proportional contributions in four basal carbon sources of different trophic groups in the downstream (backwater zone) of the Daning River. 
Table 3. Intergroup dissimilarity for each trophic group in the downstream (backwater zone) of the Daning River.

\begin{tabular}{ccccc}
\hline Intergroup Dissimilarity (\%) & Benthivores & Herbivores & Omnivores & Piscivores \\
\hline Herbivores & 20.36 & & & \\
Omnivores & 20.87 & 13.36 & & \\
Piscivores & 16.86 & 10.77 & 15.56 & \\
Planktivores & 22.42 & 33.03 & 31.38 & 27.84 \\
\hline
\end{tabular}

\section{Discussion}

\subsection{The Relative Importance of Four Basic Carbon Sources}

The SIAR model estimates indicated that riparian $\mathrm{C}_{3}$ plants were the primary carbon source consistently supporting fish biomass in both the downstream and upstream of the Daning River. However, terrestrial $\mathrm{C}_{4}$ plants were relatively unimportant and contributed the least fraction of biomass for most fish species. Our results conform to a number of previous studies that certain terrestrial carbon, namely $C_{3}$ macrophytes rather than $C_{4}$ vegetation from the riparian zone, provide major support to consumers $[8,9,37,38]$. Nevertheless, these outcomes contradict, to some extent, a recent study reporting the importance of $\mathrm{C}_{4}$ plants as one of the dominant carbon sources in the TGD [24].

Our results also demonstrated that the average contribution from seston was similar to $C_{3}$ plants regardless of feeding type, and that 13 fish species still had lower $95 \%$ credibility intervals greater than zero in the downstream. This highlights the relative importance of seston as a carbon source especially to downstream fish. Meanwhile, benthic algae as a potential carbon subsidy to upstream fish, was also observed. Given that the seston in the limnetic zone comprised mainly of planktonic algae, it is reasonable to conclude that autochthonous food sources (aquatic algae) in the Daning River serve as certain unneglectable and vital supports to fish production. This finding is consolidated by studies of other reservoirs $[8,16]$ and rivers [39-41] where algal carbon of either suspended or benthic origin is considered to be of much importance.

The lower importance of terrestrial $C_{4}$ plants to fish species observed in our study conflicts with the result from the main river channel of the Yangtze River [24]. The authors argued that terrestrial $C_{4}$ carbon is as important a contribution as $\mathrm{C}_{3}$ carbon because of inadequate algal production, potential high quality of terrestrial plant parts or detritus and invertebrate processing of indigestible terrestrial vegetation [24]. Resource quality, rather than availability, is the likely explanation of less assimilation of $C_{4}$ material in the Daning River [42-44], considering that $C_{3}$ and $C_{4}$ plants are both abundant in flood plains along this tributary, particularly, in periodically inundated areas in the downstream. As consumers reveal a preference for high-quality food resources, determining the upper trophic level consumers' production despite its origin and quantity [43,45], $\mathrm{C}_{3}$ plants (with lower $\mathrm{C} / \mathrm{N}$ ratio) and algae are more palatable and digestible providing an efficient energy source compared to $\mathrm{C}_{4}$ plants, even via the invertebrate transfer pathway. This phenomenon is also demonstrated in the central Amazon River system where the importance of carbon source from plant groups is not proportional to their total production $[42,46,47]$.

\subsection{Spatial Variation of Carbon Source Contribution}

In spite of the dominant carbon source from $C_{3}$ in the stream, the distinction in trophic pathway between the upper and lower reaches was still evident. Besides $C_{3}$ vegetation, fish species from the downstream appeared to be supported by seston, whereas upstream fish consumers seemed to assimilate much less (Figure 4). This could be explained by the composition of this carbon source where seston from the upstream consisted of detritus derived primarily from terrestrial plant production, which was confirmed by the fact that seston from the lotic water zone had an isotopic signature aligned 
with $\mathrm{C}_{4}$ terrestrial vegetation (Figure 2, with large overlap). Instead, planktonic algae were the main components of the downstream seston through microscope inspection, as mentioned above.

The perceptible difference in carbon pathway patterns in the Daning River relates to divergent landscape-scale hydrologic characteristics in the different reaches as described in many other riverine studies $[8,13,16]$. Due to the impoundment of the TGR, the lacustrine environment has been shaped in the downstream with water velocity sharply halted and water depth gradually deepening along the tributary. The large periodic inundated zone in open sections covers plentiful riparian macrophytes and grass during the lower-water-level period, which become potential carbon sources to fish consumers when water rises through decomposition or invertebrate processing [9]. Meanwhile, the higher water transparency as a result of sedimentation, as well as longer water residence times in the backwater zones, could promote algal growth [48] that accounts for the potential importance of phytoplankton as a carbon source in the downstream. Actually, the downstream has been mesotrophic since impoundment and algae bloom usually takes place in May-October at these open sections [26]. Additionally, the rocky substrate along the downstream steep littoral zones also provides ample opportunities for attachment of epiphytic algae and collection of detritus. In the upper fluvial channel, however, relatively high water velocity constrains suspended algae biomass and results in seston mostly from agitation of benthic detritus dominated by terrestrial organic matter [49], accounting for the reduced importance of this source compared to the downstream. In the upstream, conversely, the flat valley characterized by shallow water and rocky substrate appears to provide suitable conditions for the production of riparian plants and benthic algae supporting fish consumers.

\subsection{The Carbon Pathway in the Influenced Backwater Zone}

In our study, fish groups relied on inputs of algae less than riparian $C_{3}$ carbon, which is not fully consistent with the RPM that have increasingly emphasized the importance of algal carbon with little importance of riparian inputs $[3,5,6]$. The RPM is supposed to be applied to reservoirs or impounded sections where fish consumers rely mainly on pelagic-derived nutrients as observed in many other studies $[7,8,13,14]$. In the early period (nearly one year) after the TGR impoundment, significant increases in phytoplankton production at the lacustrine zone had not yet enhanced planktonic algal contribution to consumers [24]. The shorter time scale following TGD completion, as well as the limited availability for algal carbon to the consumer taxa, are credited as the explanations for these lower contributions [24]. After nearly ten years of TGR operation, the significance of planktonic algae in the impounded sections has gradually increased (Table 1). Nevertheless, the riparian carbon source remains as a major support to this newly-formed reservoir. Despite relative scarcity of algal carbon to massive fish biomass resulting from the small euphotic zone relative to the deep water column [24,50], we infer that hydrologic characteristics including water mixing processes in the backwater area [51] are critical factors to influencing the contribution of algal carbon. An evident alternation of the thermal stratification (May-September) and mixing (October-February) periods are strongly associated with the hydrologic regime, as surveyed in the Daning River [50]. The thermal stratification emerges during the flood season [50] when the water level is low and the inflows are relatively high in the downstream. However, a previous report has confirmed that the flow velocities are not capable of disturbing the development of thermal stratification in this river [52]. A high biomass of phytoplankton (or occasionally algae blooms) caused by high water temperature $[50,53]$ are restricted to the epilimnion due to the relative stability of the water column, which also prevents internal circulation of nutrients that confine the extent and range of phytoplankton growth [54]. In addition, a majority of the annual precipitation in the Daning River valley falls during this stratification period, bringing a large amount of terrestrial carbon nutrients into the water [26]. On the other side, during the dry season (October-February) when the water level rises (for power generation and navigation), the water from the TGR mainstream flows back into the tributaries [51] and severely disrupts the thermal stratification causing rapid mixing of water bodies [50]. Nevertheless, the decreasing temperature in these seasons (winter and spring) limits the total cumulative biomass of algae, whereas the rising water storage 
inundates a large area of open valley with enormous riparian plant growth. Therefore, these periodic hydrologic regimes provide great opportunities for fish consumers to feed on the riparian carbon sources. In conclusion, the primary carbon sources for fish consumers have been dominated by the riparian material so far, which stressed the vital subsidization of terrestrial carbon to aquatic food webs in large rivers and their tributaries.

\subsection{The Influence of Diet Strategies on the Importance of Major Carbon Sources}

The feeding strategies influenced the proportions of different resources consumed according to distinct feeding groups, but have not altered $C_{3}$ plants as the dominant carbon source within each group (Figure 5). The result is in contrast to studies conducted in other rivers or lakes where the most important carbon sources for different feeding groups vary widely [55,56]. It is plausible that fish consumers are expected to have more contributions from diets they prefer or from their selective foraging strategies, which are linked to morphological or physiological characteristics $[57,58]$ as well as food availability $[59,60]$. However, many fish species can alter their diet opportunistically in response to the relative abundance and quality of food to maximize energy and nutritional gains relative to costs [61,62]. Dietary similarity for different species may occur in a system where food resources are abundant $[63,64]$. Therefore, the constancy of $C_{3}$ carbon supports for distinct feeding groups is probably attributed to unrestricted and sustained carbon subsidies from nutritious $C_{3}$ plants in the Daning River. Moreover, fish, as secondary or tertiary consumers for most species, are likely generalists, exhibiting trophic plasticity in accordance with resource availability or habitat features, rather than restrictive specialists $[15,59,65,66]$. This is the case even for species with remarkable morphological adaptations such as silver carp, Hypophthalmichthys molitrix, which have evolved specialized filter apparatuses showing temporal variations in prey species compositions in previous reports $[67,68]$. Aside from feeding on riparian plants directly, they could also integrate carbon source pathways of primary consumers in proportions, such as zooplankton or benthic invertebrates, which may assimilate carbon derived from $\mathrm{C}_{3}$ plants. In our study, the disparity in the contribution of each source for omnivores was less divergent than other groups probably because of their more generalist feeding habits. Furthermore, it is reported that similar isotope compositions of two sources pooled in the analysis may obscure the relative importance of contribution [47,69]. Underlying crucial carbon sources may be masked given the broad range of possible of solutions due to the large overlap of seston and $\mathrm{C}_{3}$ plant isotope values in our models.

\section{Conclusions}

This study indicates that riparian $C_{3}$ plants were the major energy source supporting fish consumers in a tributary of the TGR. Aquatic algae were also an important secondary carbon source, but the components of algae changed spatially in the river with planktonic algae being dominant in the downstream and benthic algae in the upstream. This is possibly a result of different landscape-scale hydrologic characteristics within the stream. $\mathrm{C}_{4}$ plants provided little support for fish consumers even though they were plentiful along the riparian. The lower quality of $\mathrm{C}_{4}$ plants that affected food source utilization, compared to $\mathrm{C}_{3}$ carbon, may account for this discrepancy. The comparatively lesser importance of algae to riparian $C_{3}$ carbon in the backwater area does not fully support the RPM. However, our results emphasize the consistent carbon subsidies from riparian terrestrial plants in the lacustrine zone after nearly ten years of e impoundment of the TGR. In agreement with the limited availability of algal carbon in this zone, another explanation is the hydrologic regime of the water-level-fluctuation cycle in the downstream, restricting algal carbon biomass production and promoting the opportunity of riparian $\mathrm{C}_{3}$ vegetation with its decaying detritus assimilation. Moreover, the feeding strategies did not shift $\mathrm{C}_{3}$ plants to being the dominant carbon source for all the species, indicating that an abundant carbon source of nutritious $C_{3}$ plants emerging along the Daning River support this typical tributary. 
Supplementary Materials: The following are available online at http:/ /www.mdpi.com/2073-4441/10/9/1233/ s1. Table S1. Summary of stable isotope compositions $\left(\delta^{13} \mathrm{C}\right.$ and $\delta^{15} \mathrm{~N}$, mean $\left.\pm \mathrm{SD}\right)$ for basal carbon sources and fish collected from the Daning River.

Author Contributions: Conceptualization, H.D., D.C., and Y.L.; Investigation, H.D., M.L. and X.D.; Writing-Original Draft Preparation, H.D.; Writing-Review \& Editing, H.D., Y.L., M.L., S.L. and D.C.

Funding: This research was funded by the Hubei Key Laboratory of the Three Gorges Project for Conservation of Fishes (Grant NO. SXSN14381).

Acknowledgments: We are grateful to Ke Yuan for the assistance with laboratory analysis of carbon and nitrogen isotope ratios.

Conflicts of Interest: The authors declare no conflict of interest.

\section{References}

1. Vannote, R.L.; Minshall, G.W.; Cummins, K.W.; Sedell, J.R.; Cushing, C.E. The river continuum concept. Can. J. Fish. Aquat. Sci. 1980, 37, 130-137. [CrossRef]

2. Junk, W.J.; Bayley, P.B.; Sparks, R.E. The flood pulse concept in river-floodplain systems. Can. Spec. Publ. Fish. Aquat. Sci. 1989, 106, 110-127.

3. Thorp, J.H.; Delong, M.D. The riverine productivity model: An heuristic view of carbon sources and organic processing in large river ecosystems. Oikos 1994, 70, 305-308. [CrossRef]

4. Pingram, M.A.; Collier, K.J.; Hamilton, D.P.; David, B.O.; Hicks, B.J. Carbon sources supporting large river food webs: A review of ecological theories and evidence from stable isotopes. Freshw. Rev. 2012, 5, 85-103. [CrossRef]

5. Thorp, J.H.; Delong, M.D.; Greenwood, K.S.; Casper, A.F. Isotopic analysis of three food web theories in constricted and floodplain regions of a large river. Oecologia 1998, 117, 551-563. [CrossRef] [PubMed]

6. Thorp, J.H.; Delong, M.D. Dominance of autochthonous autotrophic carbon in food webs of heterotrophic rivers. Oikos 2002, 96, 543-550. [CrossRef]

7. Delong, M.D.; Thorp, J.H. Significance of instream autotrophs in trophic dynamics of the Upper Mississippi River. Oecologia 2006, 147, 76-85. [CrossRef] [PubMed]

8. Hoeinghaus, D.J.; Winemiller, K.O.; Agostinho, A.A. Landscape-scale hydrologic characteristics differentiate patterns of carbon flow in large-river food webs. Ecosystems 2007, 10, 1019-1033. [CrossRef]

9. Zeug, S.C.; Winemiller, K.O. Evidence supporting the importance of terrestrial carbon in a large-river food web. Ecology 2008, 89, 1733-1743. [CrossRef] [PubMed]

10. Thorp, J.H.; Thoms, M.C.; Delong, M.D. The riverine ecosystem synthesis: Biocomplexity in river networks across space and time. River Res. Appl. 2006, 22, 123-147. [CrossRef]

11. Thorp, J.H.; Thoms, M.C.; Delong, M.D. The Riverine Ecosystem Synthesis, 1st ed.; Elsevier: London, UK, 2008.

12. Humphries, P.; Keckeis, H.; Finlayson, B. The river wave concept: Integrating river ecosystem models. BioScience 2014, 64, 870-882. [CrossRef]

13. Mercado-Silva, N.; Helmus, M.R.; Zanden, M.J.V. The effects of impoundment and non-native species on a river food web in Mexico's central plateau. River Res. Appl. 2009, 25, 1090-1108. [CrossRef]

14. Freedman, J.A.; Lorson, B.D.; Taylor, R.B.; Carline, R.F.; Stauffer, J.R. River of the dammed: Longitudinal changes in fish assemblages in response to dams. Hydrobiologia 2014, 727, 19-33. [CrossRef]

15. Carvalho, D.R.; Castro, D.; Callisto, M.; Moreira, M.Z.; Pompeu, P.S. Isotopic variation in five species of stream fishes under the influence of different land uses. J. Fish Biol. 2015, 87, 559-578. [CrossRef] [PubMed]

16. Kaymak, N.; Winemiller, K.O.; Akin, S.; Altuner, Z.; Polat, F.; Dal, T. Stable isotope analysis reveals relative influences of seasonal hydrologic variation and impoundment on assimilation of primary production sources by fish in the Upper Yesilırmak River, Turkey. Hydrobiologia 2015, 753, 131-147. [CrossRef]

17. Delong, M.D.; Thoms, M.C. Changes in the trophic status of fish feeding guilds in response to flow modification. J. Geophys. Res. Biogeosci. 2016, 121, 949-964. [CrossRef]

18. Herwig, B.R.; Wahl, D.H.; Detters, J.M.; Soluk, D.A. Spatial and temporal patterns in the food web structure of a large floodplain river assessed using stable isotopes. Can. J. Fish. Aquat. Sci. 2007, 64, 495-508. [CrossRef]

19. Poole, G.C. Stream hydrogeomorphology as a physical science basis for advances in stream ecology. J. N. Am. Benthol. Soc. 2010, 29, 12-25. [CrossRef] 
20. Power, M.E.; Dietrich, W.E.; Finlay, J.C. Dams and downstream aquatic biodiversity: Potential food web consequences of hydrologic and geomorphic change. Environ. Manag. 1996, 20, 887-895. [CrossRef]

21. Doi, H.; Chang, K.H.; Ando, T.; Imai, H.; Nakano, S.I.; Kajimoto, A.; Katano, I. Drifting plankton from a reservoir subsidize downstream food webs and alter community structure. Oecologia 2008, 156, 363-371. [CrossRef] [PubMed]

22. Wellard Kelly, H.A.; Rosi-Marshall, E.J.; Kennedy, T.A.; Hall, R.O., Jr.; Cross, W.F.; Baxter, C.V. Macroinvertebrate diets reflect tributary inputs and turbidity-driven changes in food availability in the Colorado River downstream of Glen Canyon Dam. Freshw. Sci. 2013, 32, 397-410. [CrossRef]

23. Fernandes, C.C.; Podos, J.; Lundberg, J.G. Amazonian ecology: Tributaries enhance the diversity of electric fishes. Science 2004, 305, 1960-1962. [CrossRef] [PubMed]

24. Wang, J.; Gu, B.; Huang, J.; Han, X.; Lin, G.; Zheng, F.; Li, Y. Terrestrial contributions to the aquatic food web in the middle Yangtze River. PLoS ONE 2014, 9, e102473. [CrossRef] [PubMed]

25. Li, B.; Wang, Z.J.; Yue, X.J.; Wang, Y.M.; Jin, L.; Zhang, Y.G. Influence of 175-m-impoundment in Three Gorges Reservoir Area on the food web energy sources of main commercial fishes in backwater area of Xiaojiang River. Chin. J. Appl. Ecol. 2013, 24, 1715-1721.

26. Deng, C. Studies on Entrophication in the Three Gorgers Reservoir, 1st ed.; China Environmental Science Press: Beijing, China, 2007.

27. Hang, Y. Study on Pollution Character and Water Environment Impact of the Wet-Dry Zones in the Three Gorges Reservoir. Ph.D. Thesis, Chongqing University, Chongqi, China, 2007.

28. Shen, Z.; Hong, Q.; Yu, H.; Liu, R. Parameter uncertainty analysis of the non-point source pollution in the Daning River watershed of the Three Gorges Reservoir Region, China. Sci. Total Environ. 2008, 405, 195-205. [CrossRef] [PubMed]

29. Yang, F.; Yao, W.Z.; Deng, H.T.; Chen, D.Q.; Liu, S.P.; Duan, X.B. The current situation of fish resources in the Daning River after the impoundment of the Three Gorges Reservoir. Freshw. Fish. 2013, 43, 51-57.

30. The Fish Laboratory of Institute Hydrobiology of Hubei Province. Fishes in the Yangtze River, 1st ed.; Science Press: Beijing, China, 1976.

31. Zeng, X.Z. Fishery Resources of the Yangtze River Basin, 1st ed.; Marine Press: Beijing, China, 1990.

32. Ding, R.H. The Fishes of Sichuan, 1st ed.; Sichuan Publishing House of Science and Technology: Chengdu, China, 1994.

33. Zhang, T.L. Life-History Strategies, Trophic Patterns and Community Structure in the Fishes of Lake Biandantang. Ph.D. Thesis, Graduate University of the Chinese Academy of Sciences, Wuhan, China, 2005; pp. 61-118.

34. Parnell, A.C.; Inger, R.; Bearhop, S.; Jackson, A.L. Source partitioning using stable isotopes: Coping with too much variation. PLoS ONE 2010, 5, e9672. [CrossRef] [PubMed]

35. Post, D.M. Using stable isotopes to estimate trophic position: Models, methods, and assumptions. Ecology 2002, 83, 703-718. [CrossRef]

36. Vander Zanden, M.J.; Rasmussen, J.B. Variation in $\delta^{15} \mathrm{~N}$ and $\delta^{13} \mathrm{C}$ trophic fractionation: Implications for aquatic food web studies. Limnol. Oceanogr. 2001, 46, 2061-2066. [CrossRef]

37. Marchese, M.R.; Saigo, M.; Zilli, F.L.; Capello, S.; Devercelli, M.; Montalto, L.; Paporello, G.; Wantzen, K.M. Food webs of the Paraná River floodplain: Assessing basal sources using stable carbon and nitrogen isotopes. Limnologica 2014, 46, 22-30. [CrossRef]

38. Zeng, Y.; Lai, Z.; Yang, W.; Li, H. Stable isotopes reveal food web reliance on different carbon sources in a subtropical watershed in South China. Limnologica 2018, 69, 39-45. [CrossRef]

39. Leigh, C.; Burford, M.A.; Sheldon, F.; Bunn, S.E. Dynamic stability in dry season food webs within tropical floodplain rivers. Mar. Freshw. Res. 2010, 61, 357-368. [CrossRef]

40. Pingram, M.A.; Collier, K.J.; Hamilton, D.P.; Hicks, B.J.; David, B.O. Spatial and temporal patterns of carbon flow in a temperate, large river food web. Hydrobiologia 2014, 729, 107-131. [CrossRef]

41. Neres-Lima, V.; Brito, E.F.; Krsulović, F.A.; Detweiler, A.M.; Hershey, A.E.; Moulton, T.P. High importance of autochthonous basal food source for the food web of a Brazilian tropical stream regardless of shading. Int. Rev. Hydrobiol. 2016, 101, 132-142. [CrossRef]

42. Forsberg, B.R.; Araujo-Lima, C.A.R.M.; Martinelli, L.A.; Victoria, R.L.; Bonassi, J.A. Autotrophic carbon sources for fish of the central Amazon. Ecology 1993, 74, 643-652. [CrossRef] 
43. Marcarelli, A.M.; Baxter, C.V.; Mineau, M.M.; Hall, R.O. Quantity and quality: Unifying food web and ecosystem perspectives on the role of resource subsidies in freshwaters. Ecology 2011, 92, 1215-1225. [CrossRef] [PubMed]

44. Carroll, T.M.; Thorp, J.H.; Roach, K.A. Autochthony in karst spring food webs. Hydrobiologia 2016, 776, 173-191. [CrossRef]

45. Brett, M.T.; Bunn, S.E.; Chandra, S.; Galloway, A.W.; Guo, F.; Kainz, M.J.; Kankaala, P.; Lau, D.C.; Moulton, T.P.; Power, M.E.; et al. How important are terrestrial organic carbon inputs for secondary production in freshwater ecosystems? Freshw. Biol. 2017, 62, 833-853.

46. Oliveira, A.C.B.; Soares, M.G.M.; Martinelli, L.A.; Moreira, M.Z. Carbon sources of fish in an Amazonian floodplain lake. Aquat. Sci. 2006, 68, 229-238. [CrossRef]

47. Mortillaro, J.M.; Pouilly, M.; Wach, M.; Freitas, C.E.C.; Abril, G.; Meziane, T. Trophic opportunism of central Amazon floodplain fish. Freshw. Biol. 2015, 60, 1659-1670. [CrossRef]

48. Roach, K.A.; Winemiller, K.O.; Davis, S.E., III. Autochthonous production in shallow littoral zones of five floodplain rivers: Effects of flow, turbidity and nutrients. Freshw. Biol. 2014, 59, 1278-1293. [CrossRef]

49. Finlay, J.C. Stable-carbon-isotope ratios of river biota: Implications for energy flow in lotic food webs. Ecology 2001, 82, 1052-1064. [CrossRef]

50. Zhu, K.; Bi, Y.; Hu, Z. Responses of phytoplankton functional groups to the hydrologic regime in the Daning River, a tributary of Three Gorges Reservoir, China. Sci. Total Environ. 2013, 450, 169-177. [CrossRef] [PubMed]

51. Zhao, Y.; Zheng, B.; Wang, L.; Qin, Y.; Li, H.; Cao, W. Characterization of mixing processes in the confluence zone between the Three Gorges Reservoir mainstream and the Daning River using stable isotope analysis. Environ. Sci. Technol. 2015, 50, 9907-9914. [CrossRef] [PubMed]

52. Holbach, A.; Wang, L.; Chen, H.; Hu, W.; Schleicher, N.; Zheng, B.; Norra, S. Water mass interaction in the confluence zone of the Daning River and the Yangtze River-A driving force for algal growth in the Three Gorges Reservoir. Environ. Sci. Pollut. Res. 2013, 20, 7027-7037. [CrossRef] [PubMed]

53. Zhang, J.L.; Zheng, B.H.; Liu, L.S.; Wang, L.P.; Huang, M.S.; Wu, G.Y. Seasonal variation of phytoplankton in the DaNing River and its relationships with environmental factors after impounding of the Three Gorges Reservoir: A four-year study. Procedia Environ. Sci. 2010, 2, 1479-1490. [CrossRef]

54. Becker, V.; Huszar, V.L.M.; Naselli-Flores, L.U.I.G.I.; Padisak, J. Phytoplankton equilibrium phases during thermal stratification in a deep subtropical reservoir. Freshw. Biol. 2008, 53, 952-963. [CrossRef]

55. Jepsen, D.B.; Winemiller, K.O. Basin geochemistry and isotopic ratios of fishes and basal production sources in four neotropical rivers. Ecol. Freshw. Fish. 2007, 16, 267-281. [CrossRef]

56. Mao, Z.G.; Gu, X.H.; Zeng, Q.F.; Chen, H.H. Carbon sources and trophic structure in a macrophyte-dominated polyculture pond assessed by stable-isotope analysis. Freshw. Biol. 2016, 61, 1862-1873. [CrossRef]

57. Webb, P.W. Body and fin form and strike tactics of four teleost predators attacking fathead minnow (Pimephales promelas) prey. Can. J. Fish. Aquat. Sci. 1984, 41, 157-165. [CrossRef]

58. Drewe, K.E.; Horn, M.H.; Dickson, K.A.; Gawlicka, A. Insectivore to frugivore: Ontogenetic changes in gut morphology and digestive enzyme activity in the characid fish Brycon guatemalensis from Costa Rican rain forest streams. J. Fish. Biol. 2004, 64, 890-902. [CrossRef]

59. Beaudoin, C.P.; Tonn, W.M.; Prepas, E.E.; Wassenaar, L.I. Individual specialization and trophic adaptability of northern pike (Esox lucius): An isotope and dietary analysis. Oecologia 1999, 120, 386-396. [CrossRef] [PubMed]

60. Correa, S.B.; Winemiller, K.O. Niche partitioning among frugivorous fishes in response to fluctuating resources in the Amazonian floodplain forest. Ecology 2014, 95, 210-224. [CrossRef] [PubMed]

61. Abrams, P.A. Life history and the relationship between food availability and foraging effort. Ecology 1991, 72, 1242-1252. [CrossRef]

62. Peterson, C.C.; Winemiller, K.O. Ontogenic diet shifts and scale-eating in Roeboides dayi, a Neotropical characid. Environ. Biol. Fish. 1997, 49, 111-118. [CrossRef]

63. Croxall, J.P.; Reid, K.; Prince, P.A. Diet, provisioning and productivity responses of marine predators to differences in availability of Antarctic krill. Mar. Ecol. Prog. Ser. 1999, 177, 115-131. [CrossRef]

64. Vaudo, J.J.; Heithaus, M.R. Dietary niche overlap in a nearshore elasmobranch mesopredator community. Mar. Ecol. Prog. Ser. 2011, 425, 247-260. [CrossRef] 
65. Winemiller, K.O. Ontogenetic diet shifts and resource partitioning among piscivorous fishes in the Venezuelan ilanos. Environ. Biol. Fish. 1989, 26, 177-199. [CrossRef]

66. Quevedo, M.; Svanbäck, R.; Eklöv, P. Intrapopulation niche partitioning in a generalist predator limits food web connectivity. Ecology 2009, 90, 2263-2274. [CrossRef] [PubMed]

67. Spataru, P.; Gophen, M. Feeding behaviour of silver carp Hypophthalmichthys molitrix Val. and its impact on the food web in Lake Kinneret, Israel. Hydrobiologia 1985, 120, 53-61. [CrossRef]

68. Ke, Z.; Xie, P.; Guo, L.; Liu, Y.; Yang, H. In situ study on the control of toxic Microcystis blooms using phytoplanktivorous fish in the subtropical Lake Taihu of China: A large fish pen experiment. Aquaculture 2007, 265, 127-138. [CrossRef]

69. Phillips, D.L.; Inger, R.; Bearhop, S.; Jackson, A.L.; Moore, J.W.; Parnell, A.C.; Semmens, B.X.; Ward, E.J. Best practices for use of stable isotope mixing models in food-web studies. Can. J. Zool. 2014, 92, 823-835. [CrossRef]

(C) 2018 by the authors. Licensee MDPI, Basel, Switzerland. This article is an open access article distributed under the terms and conditions of the Creative Commons Attribution (CC BY) license (http://creativecommons.org/licenses/by/4.0/). 